\title{
Communication
}

\section{Investigation into the Cause of Iron-Related Clogging of Groundwater Bores Used for Viticulture in the Limestone Coast, South Australia}

\author{
Birte Moser ${ }^{1,2}$, Meruyert Beknazarova ${ }^{1}{ }^{\mathbb{D}}$, Harriet Whiley ${ }^{1}{ }^{1}$, Thilini Piushani Keerthirathne ${ }^{1}$, \\ Nikki Harrington ${ }^{3}$, Kerry DeGaris ${ }^{4}$ and Ilka Wallis ${ }^{1,5, *}$
}

1 College of Science and Engineering, Flinders University, Sturt Road, Bedford Park, Adelaide, SA 5042, Australia; birte.elisabeth.moser@uni-oldenburg.de (B.M.); meruyert.cooper@flinders.edu.au (M.B.); harriet.whiley@flinders.edu.au (H.W.); Thilini.Ke@flinders.edu.au (T.P.K.)

2 Carl von Ossietzky University of Oldenburg, Ammerländer Heerstraße 114-118, 26129 Oldenburg, Germany

3 Innovative Groundwater Solutions, Unit 2/162 Hindmarsh Road, Victor Harbor, Adelaide, SA 5211, Australia; nikki@innovativegroundwater.com.au

4 Limestone Coast Grape and Wine Council, Coonawarra, SA 5263, Australia; Kerry.degaris@bigpond.com

5 National Centre for Groundwater Research and Training, Flinders University, Sturt Road, Bedford Park, Adelaide, SA 5042, Australia

* Correspondence: ilka.wallis@flinders.edu.au; Tel.: +61-08-8201-15077

\section{check for} updates

Citation: Moser, B.; Beknazarova, M.; Whiley, H.; Keerthirathne, T.P.;

Harrington, N.; DeGaris, K.; Wallis, I. Investigation into the Cause of Iron-Related Clogging of

Groundwater Bores Used for Viticulture in the Limestone Coast, South Australia. Water 2021, 13, 683. https://doi.org/10.3390/w13050683

Academic Editor:

Juan Antonio Rodríguez Díaz

Received: 19 January 2021

Accepted: 23 February 2021

Published: 3 March 2021

Publisher's Note: MDPI stays neutral with regard to jurisdictional claims in published maps and institutional affiliations.

Copyright: (c) 2021 by the authors. Licensee MDPI, Basel, Switzerland. This article is an open access article distributed under the terms and conditions of the Creative Commons Attribution (CC BY) license (https:/ / creativecommons.org/licenses/by/ $4.0 /)$.
Abstract: Iron-related clogging of boreholes, pumps and dripper lines is a significant and costly problem for irrigators worldwide. The primary cause of iron-related clogging is still debated. Previous studies have described complex interactions between biological clogging and inorganic iron/manganese oxide precipitation. This case study examined groundwater bores used for viticulture irrigation in the Limestone Coast region, a highly productive wine growing area in the SE of South Australia. Iron clogging of bore screens, pumps and dripper systems has been a persistent problem in the region and the issue is perceived to be growing, with irrigators suggesting the widespread introduction of iron-related bacteria (IRB) through drilling equipment to be the root cause of the problem. Analysis of the groundwater microbiology and inorganic chemistry found no apparent correlation between the presence of IRB and the clogging status of wells. In fact, IRB proved to be widespread throughout the limestone aquifer. However, a clear correlation could be found between clogging affected bores and the redox potential of the groundwater with the most severely affected bores strongly oversaturated in respect to iron oxide minerals. Elevated dissolved concentrations of $\mathrm{Fe}(\mathrm{II})$ thereby tended to be found in deeper bores, which also were generally more recently drilled. Following decades of less than average rainfall, a tendency to deepen bores in response to widespread declines in water levels has been documented for the SE of South Australia. The gradually widening clogging problem in the region is postulated to be related to the changes in climate in the region, with irrigators increasingly driven to rely on deeper, anoxic iron-rich groundwater resources.

Keywords: iron-clogging; iron-related bacteria; microbiological iron clogging; inorganic iron clogging

\section{Introduction}

Iron clogging within aquifers and of irrigation infrastructure is a well-known and costly problem worldwide [1,2]. The most common problems for water supply bores are the clogging of screens and filter material, thereby reducing the subsurface permeability and the coating of pipes and pumps, which reduces water throughflow rates. If the produced groundwater feeds into an irrigation system, clogging of irrigation pipes is often an added problem [3]. While iron-related clogging is widespread and has been reported from a variety of environments, the cause of the incrustation and the environmental and/or operational factors contributing to the problem are still a matter of debate. This is partly 
due to uncertainty in whether microbial activity or inorganic iron precipitation is the root cause of the problem [2].

Inorganic precipitation of iron oxides is a common occurrence in boreholes penetrating reducing groundwaters with sufficient concentration of dissolved ferric iron [4-6]. A borehole facilitates the exposure of these reducing groundwaters to atmospheric conditions allowing dissolved iron to oxidize. Abstraction may enhance the mixing of aerated and reducing waters within the well due to turbulent flow conditions, further increasing the ability for iron to precipitate. Once incrustation has commenced, the catalytic effect of iron oxides on the oxidation of $\mathrm{Fe}(\mathrm{II})$ accelerates the rate of precipitation, enhancing the problem further [7].

Iron-related biological clogging, however, is due to the metabolic activity of iron-related bacteria (IRB) such as Gallionella spp., Leptothrix spp., Thiobacillus spp. and Sphaerotilus spp. $[8,9]$. These bacteria can facilitate the transformation of soluble ferrous ions $\left(\mathrm{Fe}^{2+}\right)$ to ferric $\left(\mathrm{Fe}^{3+}\right)$ compounds with low solubility [10] and are commonly found in groundwaters [11,12]. IRB can develop and be incorporated into biofilms, which are a community of microorganisms attached to a surface by extracellular polymeric substances ((EPS) composed mainly of polysaccharides, proteins and DNA) [13]. IRB within biofilms are able to multiply profusely in boreholes due to the constant supply of nutrients that occurs through pumping [14]. Their adhesive properties facilitate the colonization of bore casings and screens, enabling them to persist despite high flow velocities [15]. This results in the build-up of solids (iron sulphides and iron hydroxides) and/or slime deposits (EPS) within the bore, pump and/or pipes [16-18].

The importance of microbial versus chemical iron oxidation is still a matter of debate. Under neutral $\mathrm{pH}$ conditions, the oxidation of ferrous iron is a rapid process if contact with oxygen or nitrate occurs [19]. It is speculated that IRB have very little effect under these conditions due to the speed of the inorganic iron precipitation reaction [20,21]. However, with decreasing oxygen concentration in the groundwater, IRB become increasingly able to compete with abiotic iron oxidation [22,23]. In natural groundwater systems, the clogging problem is likely to be attributable to a combination of microbiological and inorganic factors [2].

The Limestone Coast region in the south east of South Australia (Figure 1) has some of the most productive land in South Australia, with groundwater being the main source of water for agricultural production. It is also a unique wine growing region with over 250 growers and 15,800 ha of vineyards [24]. The region produces nearly one-third of the value of South Australia's agricultural produce from only about $2 \%$ of its land mass. Iron clogging of bores, pumps and drippers has been a persistent problem for many irrigators in the region, however, the issue is perceived to be growing [3]. Many irrigators suspect biological clogging to be the root cause of the problem and a common belief exists among irrigators that the problem is spreading due to the introduction of IRB through contaminated drilling equipment [25].

In order to investigate the cause of the widespread clogging problem, this study examines the IRB microbiology and inorganic water chemistry of bore water across two selected sub-regions of the Limestone Coast. Groundwater was analysed from a range of production bores with no, unknown or known clogging problems. Correlations between the severity of clogging and the age and depth of bores, the microbiology and the inorganic chemistry including redox conditions in these groundwaters was able to deduce the most likely cause of the clogging problem. Hypotheses were able to be drawn as to why the problem appears to be becoming more widespread. 


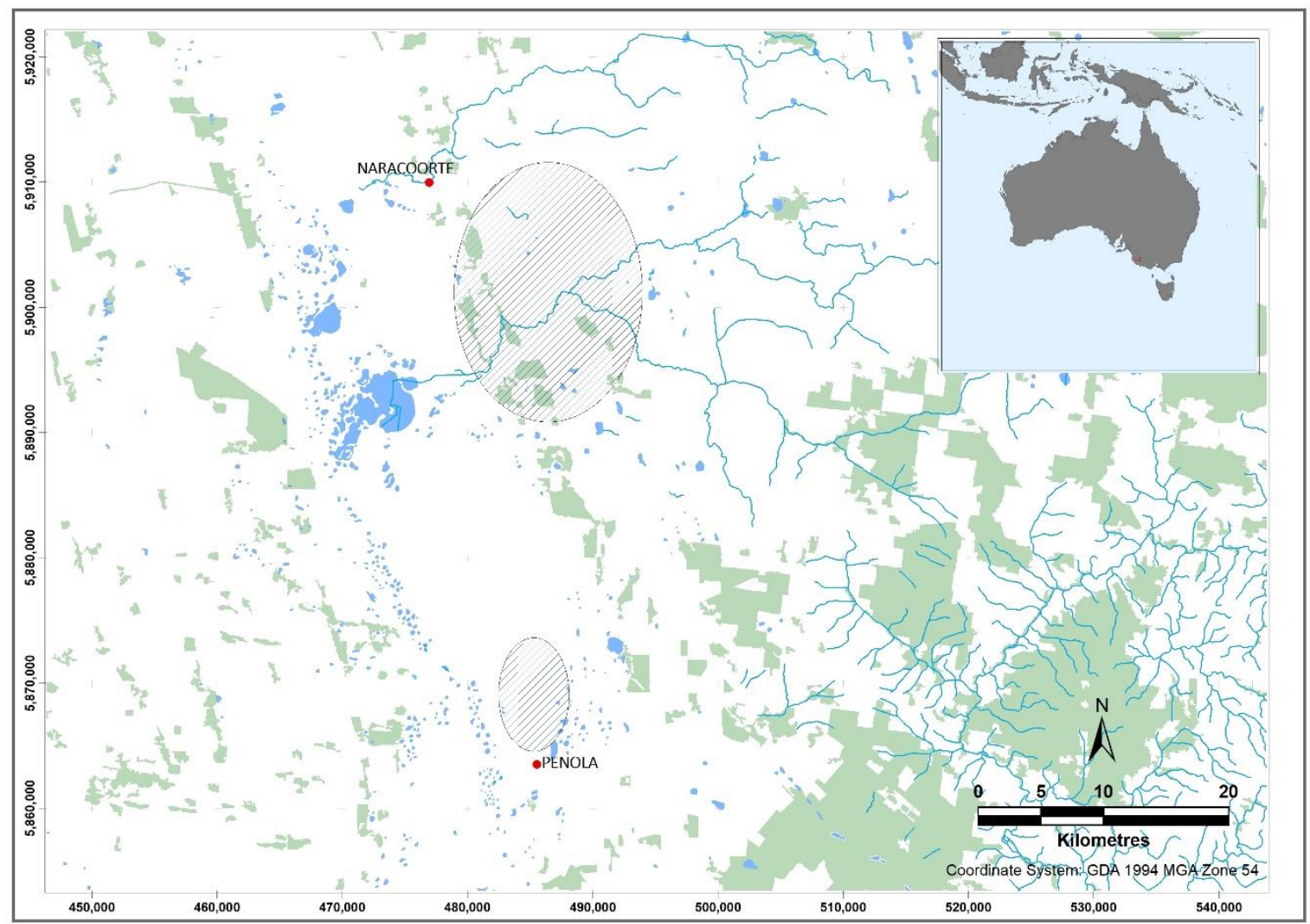

Figure 1. Location of area of investigation. Shaded oval circles indicate bore locations, however, accurate locations had to remain anonymous based on the request of landowners.

\section{Materials and Methods}

\subsection{Field Site and Groundwater Sampling}

The Limestone Coast of South Australia is located in the South East of South Australia, approximately $300 \mathrm{~km}$ south-east of Adelaide. The region is characterized by low-lying coastal plains, rising to ca. $70 \mathrm{~m}$ above sea level within the Naracoorte Ranges in the east and north-east of the region (Figure 1). The annual average rainfall in the region ranges from more than $800 \mathrm{~mm}$ in the south to $\sim 500 \mathrm{~mm}$ in the north with the climate being considered Mediterranean, with cool wet winters and mild to hot, dry summers. Most irrigation bores access the unconfined Tertiary Limestone Aquifer (TLA) in the area, with a maximum thickness of about $300 \mathrm{~m}$. The aquifer consist to a large degree of Dolomite $\left(\mathrm{CaMg}\left(\mathrm{CO}_{3}\right)\right)$ and to a lesser degree of Calcite $\left(\mathrm{CaCO}_{3}\right)$ and Siderite $\left(\mathrm{FeCO}_{3}\right)$ [26]. The unconfined aquifer is recharged mainly by diffuse rainfall and the depth to water varies between 2 and ca. $20 \mathrm{~m}$ below ground level relative to topography. Water levels have overall declined over the last few decades across the region [27]. These declines have been attributed to a combination of a significant longer-term rainfall decline over southern Australia and below average summer rainfalls over the last decades [28].

Sampling of production bores used in viticulture irrigation was conducted from October 2019 to February 2020. A total of 26 water samples were collected from wells, which, based on self-reporting by landowners, were either unaffected by clogging, affected to a minor/moderate degree or strongly affected by clogging. Two wells had uncertainty about potential clogging problems but were included in the field program as they were located in close proximity to affected wells.

\subsection{Inorganic Water Parameters}

Each well (bar two, bore number 16 and 24) was purged a minimum of three casing volumes and inorganic water samples were taken after continuous well-head measurements 
of $\mathrm{pH}$, temperature, electrical conductivity (EC), dissolved oxygen (DO) and redox potential (Eh), which indicated a stable composition, representative of the aquifer chemistry. Two aliquots were collected from each bore for inorganic analysis: (i) elemental compositions (ICP-MS, ICP-OES, filtered and acidified) and (ii) major anions (IC), DOC (Shimadzu TOC analyser) and alkalinity titration (filtered and untreated sample).

Aqueous speciation and saturation state of groundwaters in respect to common mineral phases were computed using the PHREEQC code, utilizing the PHREEQC-2 thermodynamic database [29].

\subsection{Microbiological Analysis}

Two samples were obtained from each well for the analysis of the presence of active bacterial communities including iron-related bacteria (IRB), total coliforms and Escherichia coli. Water was collected in sterilized bottles and kept refrigerated until analysed. Analysis occurred within $72 \mathrm{~h}$ following collection.

\subsubsection{IRB-BART Test}

The testing was conducted according to the manufacturer's instructions (Droycon Bioconcepts Inc., Regina, SK, Canada). Presence of IRB was indicated by a brown ring, gel and/or clouding in the test tube, indicating the production of ferric iron. The concentration of the IRB in the water sample was estimated based on the speed of the reaction. IRB were recorded for each water sample as aggressive (higher concentration when the reaction occurred within 3 days), moderate (lower concentration when the reaction occurred between 4 and 8 days) or not present.

\subsubsection{Colilert-18 Quanti-Tray Test}

Total coliforms and the presence of Escherichia coli was analysed through a Colilert18-Quanti-Tray test (IDEXX Laboratories, Inc., Westbrook, ME, USA), where undiluted bore water samples $(100 \mathrm{~mL})$ were mixed with a nutrient indicator in a sterile transparent container. The mixture was added to the Quanti-Tray and was sealed followed by overnight incubation at $37^{\circ} \mathrm{C}$. The Most Probable Number (MPN) of E. coli and total coliforms was calculated using the provided MPN table. The number of wells positive for E. coli were thereby detected by placing the Quanti-Tray under an Ultraviolet (UV, $365 \mathrm{~nm}$ ) light at least 5 inches above the Quanti-Tray.

\subsubsection{Scanning Electron Microscopy}

A single sample of the clogging material was obtained from an affected screen retrieved from a bore located on one of the properties included in the study. Samples were fixed in $4 \%$ glutaraldehyde and dehydrated by immersion in sequential ethanol solutions for 10 min per rinse starting at $1 \times 70 \% v / v$, followed by $1 \times 90 \% v / v, 1 \times 95 \% v / v$ and $2 \times 100 \% v / v$, with a final rinse in hexamethyl-disilazane (HMDS) for $30 \mathrm{~min}$. Samples were then air dried and sputter coated with $3 \mathrm{~nm}$ of platinum prior to analysis on Inspect FEI F50 Scanning Electron Microscope. This work was conducted by Flinders Microscopy and Microanalysis.

\section{Results}

\subsection{Inorganic Water Chemistry}

The groundwater in the target limestone aquifer was found to be generally fresh to slightly brackish (EC range between 1400 and $2800 \mu \mathrm{S} / \mathrm{cm}$ ) and characterized by elevated calcium and bicarbonate concentrations, indicating mineral equilibrium with the limestone (Appendix A Table A1). Accordingly, the saturation index in respect to calcite and dolomite was close to or above mineral equilibrium $(\mathrm{SI} \geq 0$ ) for all samples (Figure 2). All groundwaters were well buffered in a $\mathrm{pH}$ range of 7.4-8.0 with the dissolution of carbonate minerals providing an effective $\mathrm{pH}$ buffering mechanism, due to fast dissolution kinetics [30,31]. The groundwater was also oversaturated in respect to quartz, a further major mineral 
phase within the target aquifer, but was undersaturated with respect to gypsum, despite some groundwater samples showing elevated $\mathrm{SO}_{4}{ }^{2-}$ concentrations (Figure 2).
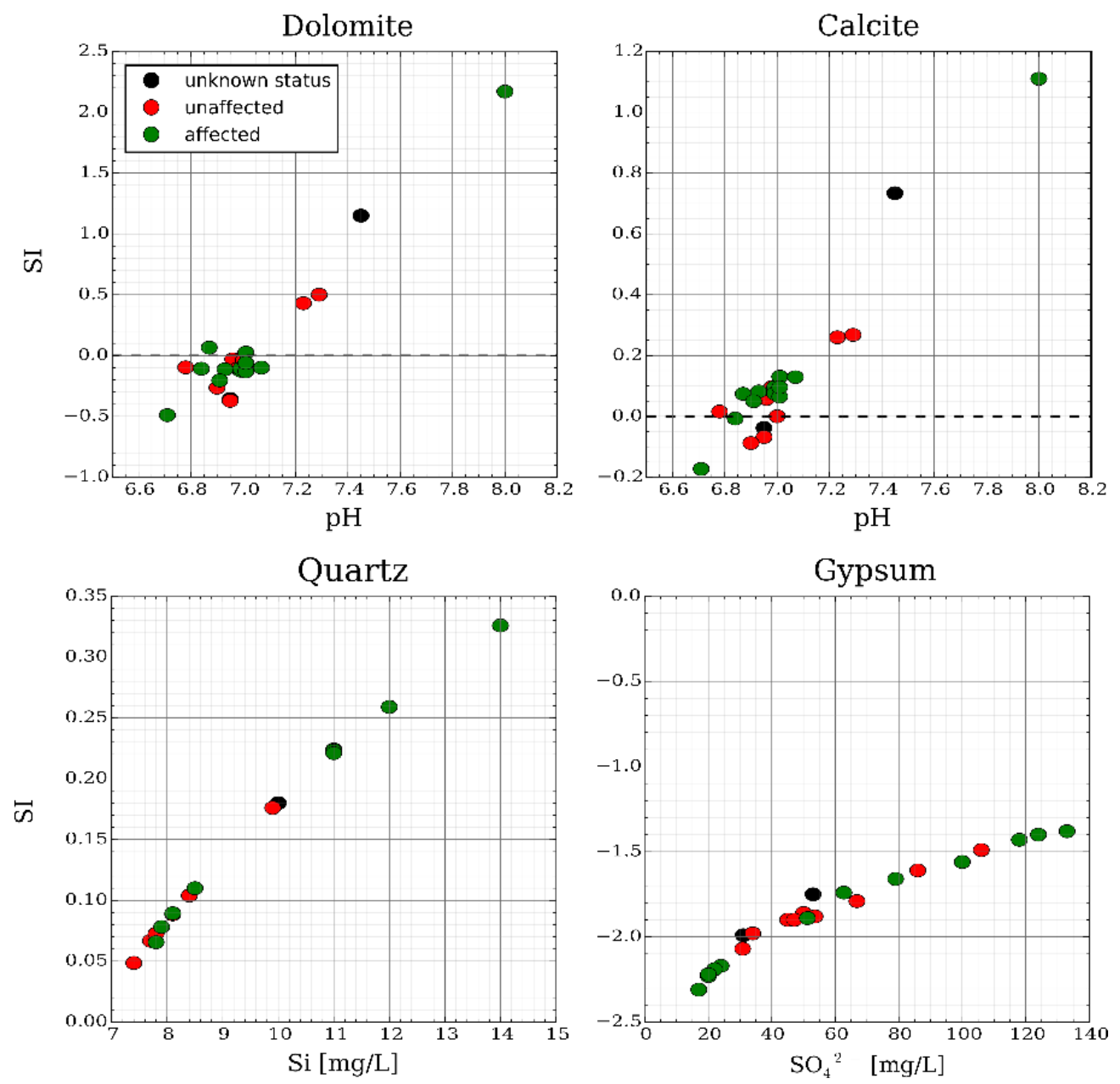

Figure 2. Correlation between the saturation index (SI) for dolomite $\left(\mathrm{CaMg}\left(\mathrm{CO}_{3}\right)_{2}\right)$, calcite $\left(\mathrm{CaCO}_{3}\right)$, quartz $\left(\mathrm{SiO}_{2}\right)$ and gypsum $\left(\mathrm{CaSO}_{4}\right)$ with dissolved $\mathrm{Ca}, \mathrm{Si}$ and $\mathrm{SO}_{4}{ }^{2}$ concentrations. The dashed line indicates mineral equilibrium $(\mathrm{SI}=0)$ with minerals likely to precipitate at $\mathrm{SI}>0$ and dissolve at $\mathrm{SI}<0$. Calculations were performed by PHREEQC using the PHREEQC-2 thermodynamic database.

Redox conditions ranged from fully oxygenated to strongly reducing waters (Figures 3 and 4). Aerated water samples were thereby characterized by elevated dissolved oxygen and nitrate concentration while reduced species (Fe(II), Mn(II)) were absent or occurred at very low concentrations. Reducing groundwaters, however, exhibited relatively high $\mathrm{Fe}(\mathrm{II})$ and $\mathrm{Mn}$ (II) concentrations, while appreciable concentrations of oxygen and nitrate were absent. In addition, several trace metal and metalloids were found to be strongly correlated to the redox status of the groundwater and indicative of oxygenated or reducing conditions. Elevated arsenic concentrations were found in reducing groundwaters, with some bores exhibiting concentrations above the drinking water guidelines (e.g., As $>10 \mu \mathrm{g} / \mathrm{L}$ ). Under reducing conditions, iron hydroxides are unstable. Their dissolution is commonly associated with a release of trace metals such as arsenic due to the corresponding loss of surface binding sites [32,33], which could explain the correlation of elevated As and Fe as shown in Figure 4. Other trace metals showed elevated mobility under aerobic, oxidizing conditions. For instance, $\mathrm{SeO}_{4}$, the most prevalent selenium species in the presence of dissolved oxygen and/or nitrate and the neutral $\mathrm{pH}$ conditions in the Tertiary Limestone Aquifer is known to be a poor sorbent and highly mobile, leading to elevated concentrations under aerobic conditions [34]. 

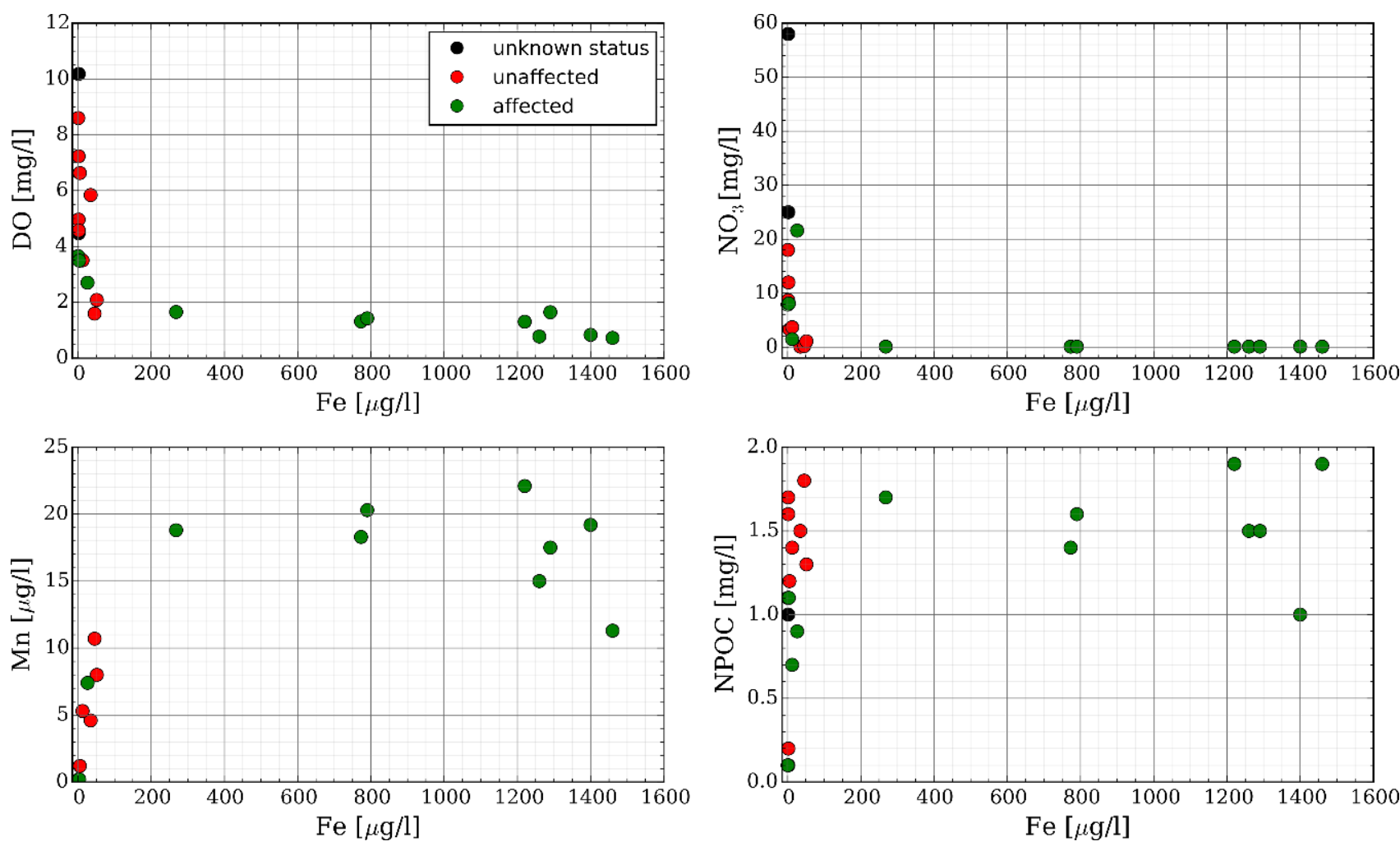

Figure 3. Correlations of Fe with redox sensitive species: dissolve oxygen (DO), nitrate $\left(\mathrm{NO}_{3}{ }^{-}\right)$, and manganese (Mn). Additionally, shown is the correlation of $\mathrm{Fe}^{2+}$ and organic matter concentrations. Green symbols relate to cloggingaffected bores, red symbols represent unaffected bores, while black symbols relate to bores where the severity of clogging was unknown.

A clear correlation between affected bores and the redox potential of the groundwater was identified. Specifically, strongly reducing waters were the most likely to be associated with clogged bores. Affected bores were found to be the most severely oversaturated in respect to iron oxide minerals, indicating a strong potential for iron precipitation if the water is exposed to oxygen (Figure 5). These ferrous-iron-rich groundwaters were also supersaturated for siderite, indicating slow siderite precipitation kinetics [35]. Besides iron mineralization, oxidation of manganese is often implicated in clogging of bores and irrigation systems [36]. However, despite elevated Mn concentrations, reducing waters remained below saturation of manganese carbonates $\left(\mathrm{MnCO}_{3}\right)$ as well as manganese oxides (Figure 5). Conversely to the above, samples from bores reported as being unaffected by clogging and all had appreciable dissolved oxygen concentrations and elevated redox potentials. If, in addition, the iron concentration was low, these groundwaters were undersaturated in respect to amorphous iron oxides $\left(\mathrm{Fe}(\mathrm{OH})_{3}\right)$, indicating a low inorganic clogging potential.

Severely affected bores were tendentially found to be deeper bores (Figure 6), while bores without clogging problems were generally shallower $(<60 \mathrm{~m})$. This reflects the natural redox sequence as residence time of groundwater increases with depth and groundwaters evolve from oxygenated to reducing waters. Higher ferrous iron concentrations are, therefore, more likely to be encountered in bores drilled to greater depth. 

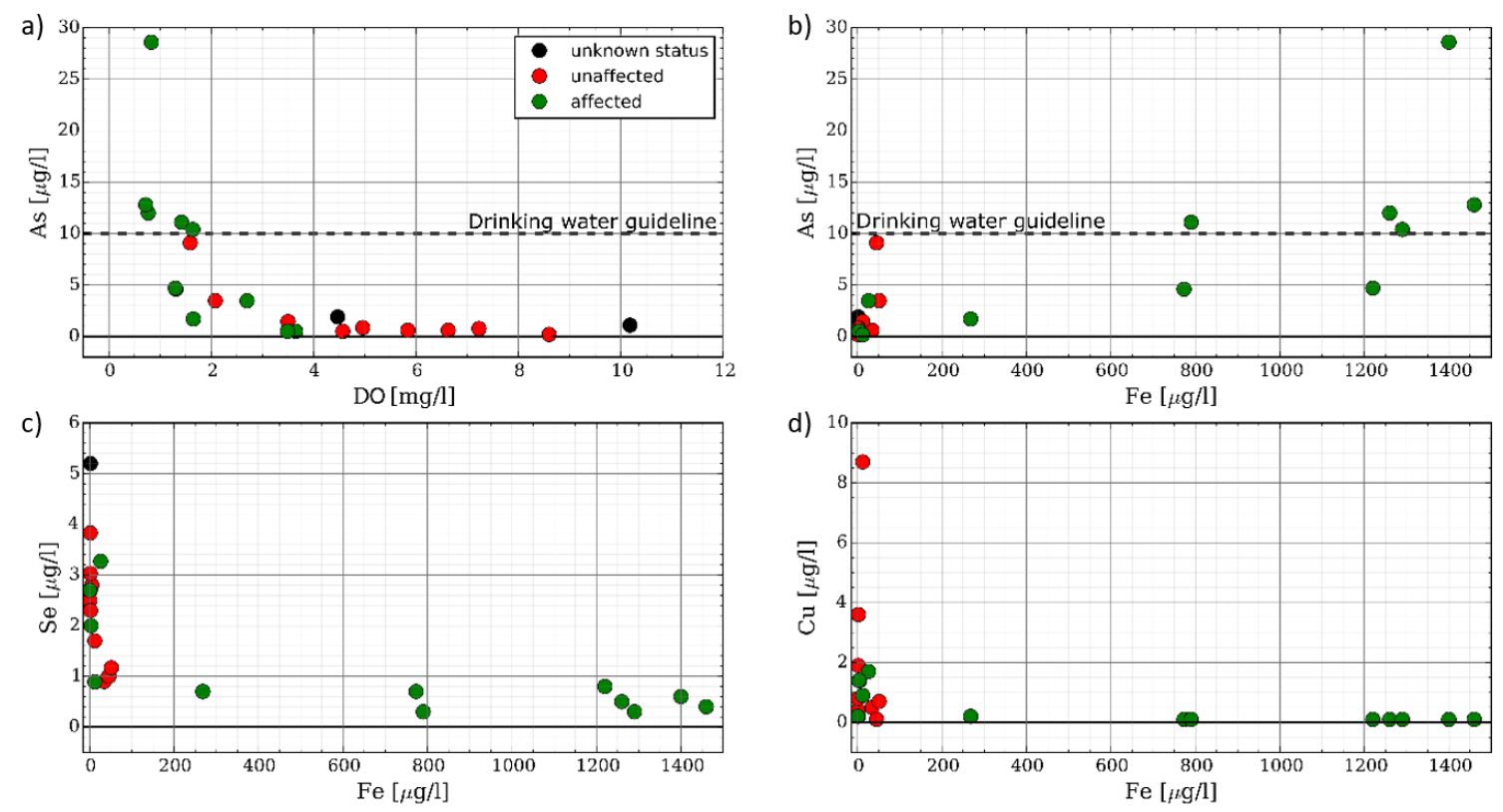

Figure 4. Trace metal and metalloid concentrations are strongly correlated to the redox conditions in groundwaters from the Tertiary Limestone Aquifer. Shown here are arsenic concentrations versus (a) dissolved oxygen, (b) ferrous iron, (c) selenium and (d) copper versus ferrous iron concentrations.
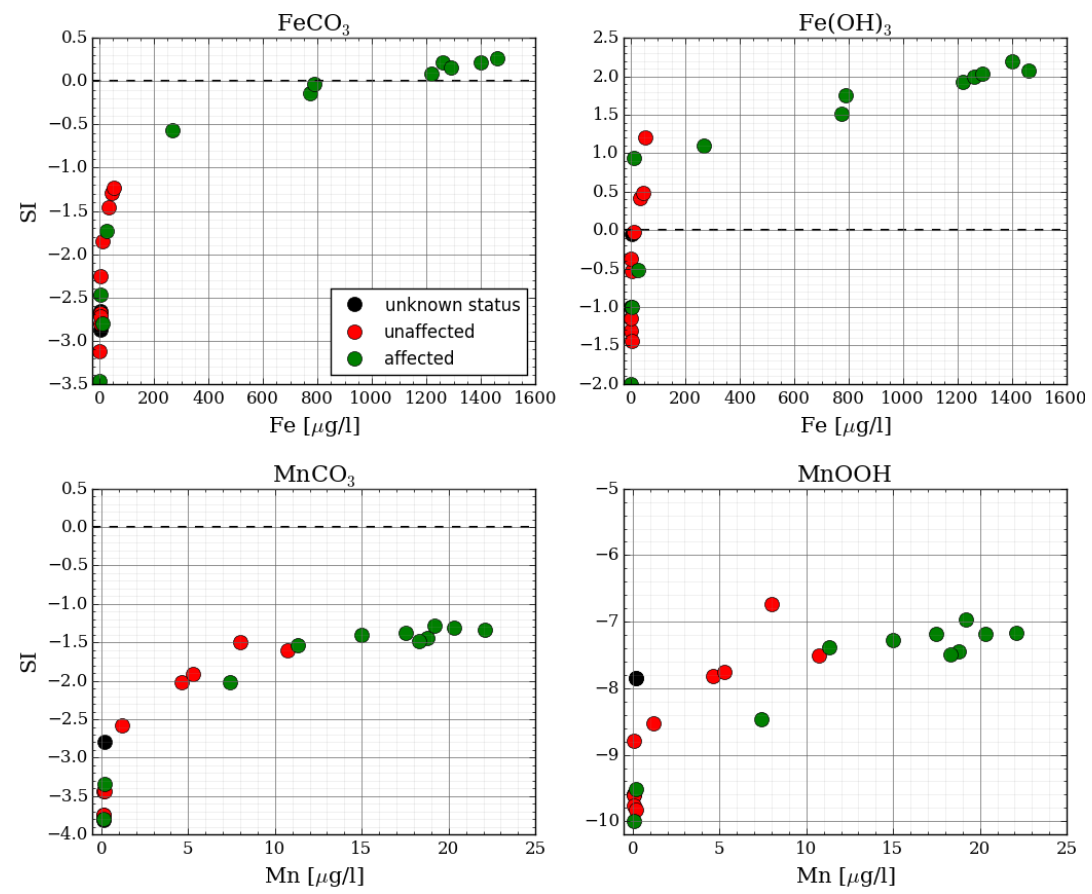

Figure 5. Correlation between $\mathrm{Fe}(\mathrm{II})$ and $\mathrm{Mn}(\mathrm{II})$ and the saturation of groundwaters in respect to the common aquifer minerals rhodochrosite $\left(\mathrm{MnCO}_{3}\right)$, siderite $\left(\mathrm{FeCO}_{3}\right)$ and iron and manganese oxides $\left(\mathrm{Fe}(\mathrm{OH})_{33}\right.$ and $\left.\mathrm{MnOOH}\right)$. The dashed line indicates mineral equilibrium $(\mathrm{SI}=0)$ with minerals likely to precipitate at SI $>0$ and dissolve at $\mathrm{SI}<0$. Green symbols relate to clogging-affected bores, red symbols represent unaffected bores, light green symbols represent mildly/moderately affected bores, while black symbols relate to bores where the severity of clogging was unknown. Calculations were performed by PHREEQC using the PHREEQC-2 thermodynamic database. 

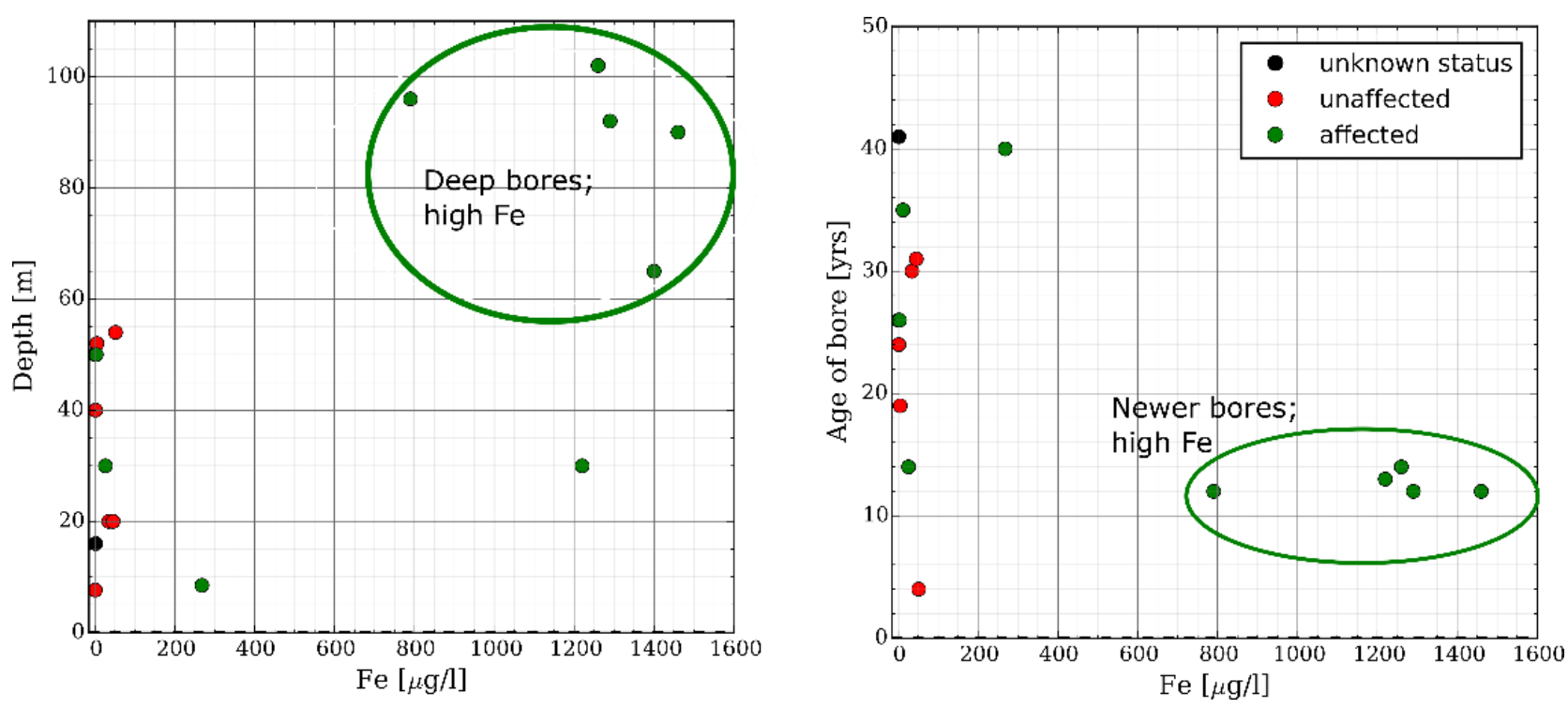

Figure 6. Correlation between the depth of bores and Fe(II) and $\mathrm{Mn}(\mathrm{II})$ concentrations as well as borehole age. Information on depth and/or age was not available for all sampled bores.

\subsection{Microbiological Analysis}

The IRB and Colilert tests indicated the presence of viable bacterial populations in the bore water samples (Appendix A Table A2). IRB was detected in $88 \%(n=21 / 25)$ of the bore water samples. Among the IRB-positive samples, five were considered to contain aggressive IRB and 17 contained moderate IRB. However, there was no correlation between the presence of IRB and the clogging status of a bore (Figure 7). There was also no correlation with the presence of IRB and the iron content, $\mathrm{pH}$, location, non-purgeable organic carbon. (NPOC), EC, temperature and DO. Two wells identified as being strongly affected by iron-related clogging were negative for IRB; however, it is unknown if these bores underwent disinfection treatments. It is possible that these were false negatives due to prior disinfection reducing the viable microorganisms to below the limit of detection.

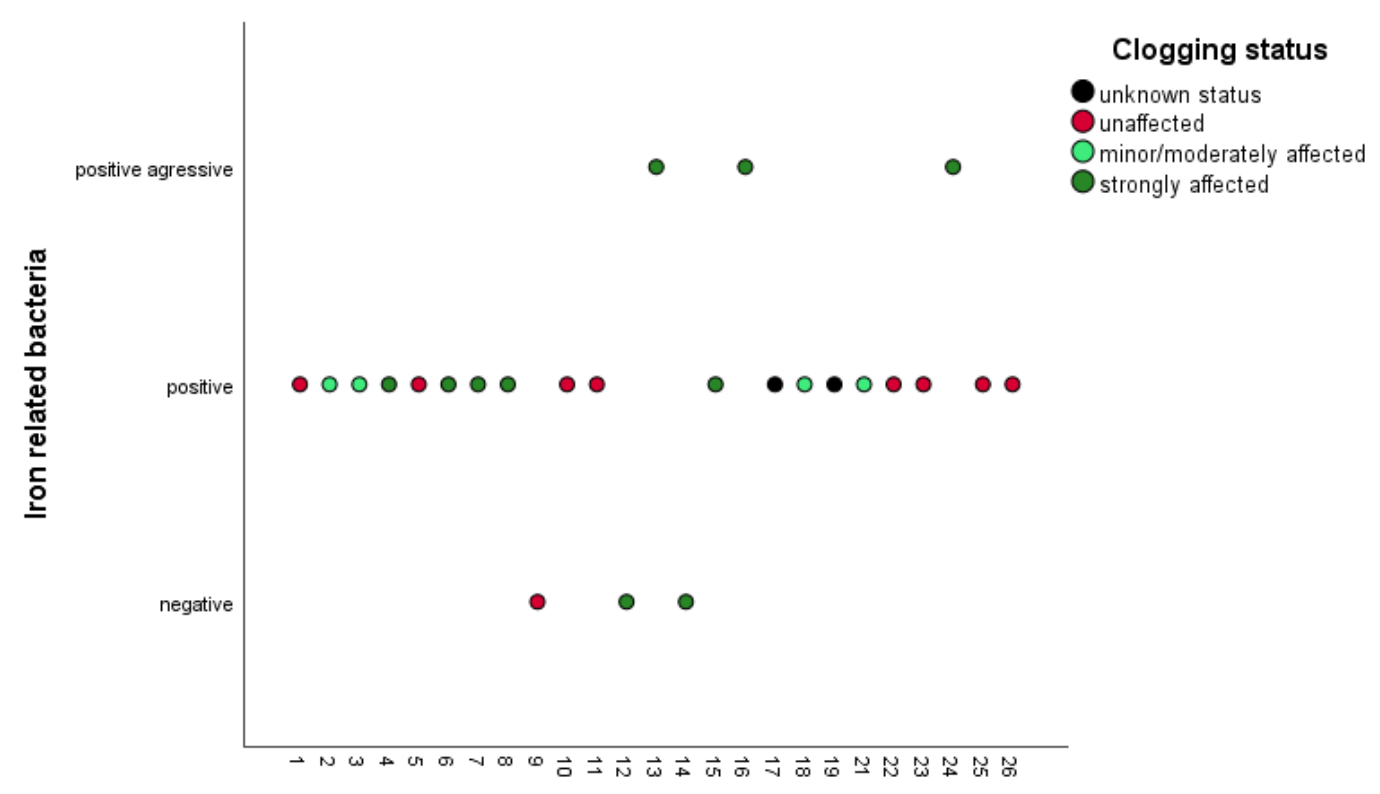

Sample ID

Figure 7. Iron-related bacteria (IRB) presence determined using the IRB Bart test and clogging status of bores. 
Twenty-two (out of 25 ) samples $(88 \%)$ and $7 / 25$ samples (28\%) were positive for coliform bacteria and E. coli, respectively. The presence of coliforms and E. coli indicate potential faecal contamination and are the most commonly used indicator organisms for microbial water quality [37]. Bores affected by E. coli correlate with very shallow bores and/or bores, where samples for bacterial analysis were taken during the first flush, prior to well purging.

The nature of the clogging material, obtained from a screen retrieved from an affected bore, was visualized through scanning electron microscope (SEM) (Figure 8). The precipitate was found to be very diverse with both crystalline structures, suggesting amorphous iron oxides, and biological structures, suggesting bacterial growth. This suggests the co-occurrence of inorganic as well as microbiological clogging.
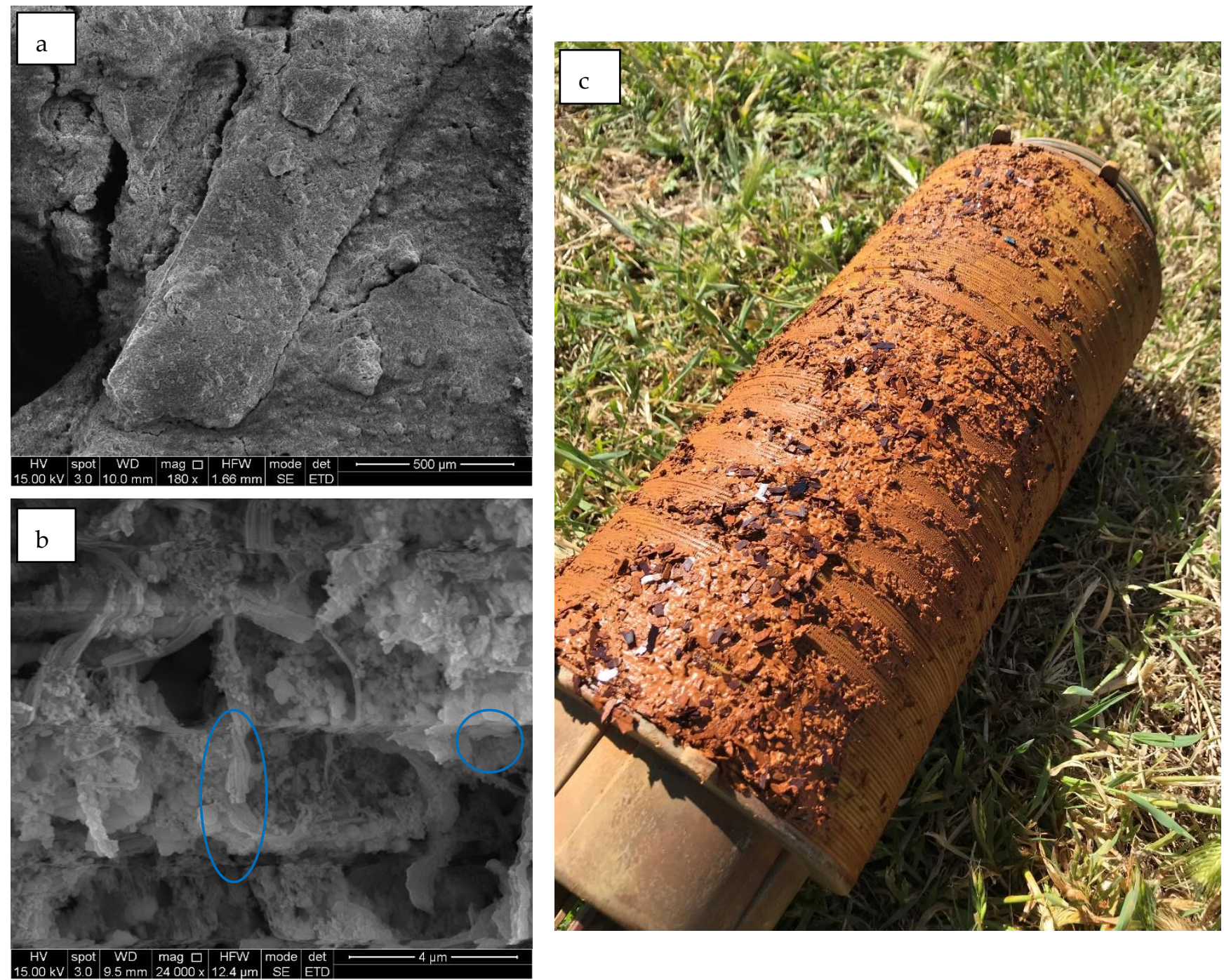

Figure 8. SEM of clogging material: (a): crystalline structure suggesting amorpheous iron oxides; (b): blue circles show the evidence of biological structure suggesting microbial growth; (c): incrustations of a clogged screen, which was sampled for SEM analysis.

\section{Discussion}

Sampling revealed that strongly reducing waters were the most likely to correlate with clogged bores. These bores were found to be the most severely oversaturated in respect to iron oxide minerals, indicating a strong potential for iron precipitation if the water is exposed to oxygen through pumping. No correlations could be found between the presence of IRB and the clogging status of a bore. There was no apparent correlation 
with the presence of IRB and the ferrous iron concentration, the $\mathrm{pH}$, location of bores, the salinity of the water, its temperature or DO concentration. Two wells were identified as being unaffected by clogging had high concentrations of IRB, and one affected well was negative for IRB. Samples with elevated organic carbon (Figure 3), however, did show a tendency to be found in bores affected by clogging. This is consistent with a higher microbiological clogging potential in the presence of dissolved carbon, as in the absence of chemical disinfectants, the degree of microbial growth is related to the amount of labile carbon in groundwater.

The aqueous chemistry and microbiology (which is supported by the SEM analysis of one sample) suggest that the widespread occurrence of reducing groundwaters with elevated iron concentrations is the primary cause of iron clogging, however, biological clogging may contribute to the problem in the area. It, therefore, appears unlikely that the perceived increase in iron clogging in the region is a result of an unintentional introduction of IRB through drilling equipment. Rather, we postulate that the documented change in regional climate, increased viticulture and irrigation demand are more likely drivers for the widening problem [38]. Since several decades, southern Australia has experienced longer-term rainfall declines with the prolonged dry spell experienced from mid 1990s to mid-2010 (the "Millennium Drought") representing the driest period in the last 110 years of reliable climate records [39]. The less than average rainfall has led to an increase in the reliance on groundwater extraction in the region, and, overall to decline in water levels [23]. Subsequently, the region has seen a tendency to drill deeper bores and deepen existing bores since the 1990s to secure irrigation supplies (Figure 9). With a higher likelihood, however, of deeper bores accessing more reducing waters, this tendency would have led to an increase in the probability of iron clogging, as redox conditions would favour higher dissolved iron concentration at depths (Figures 5 and 6).

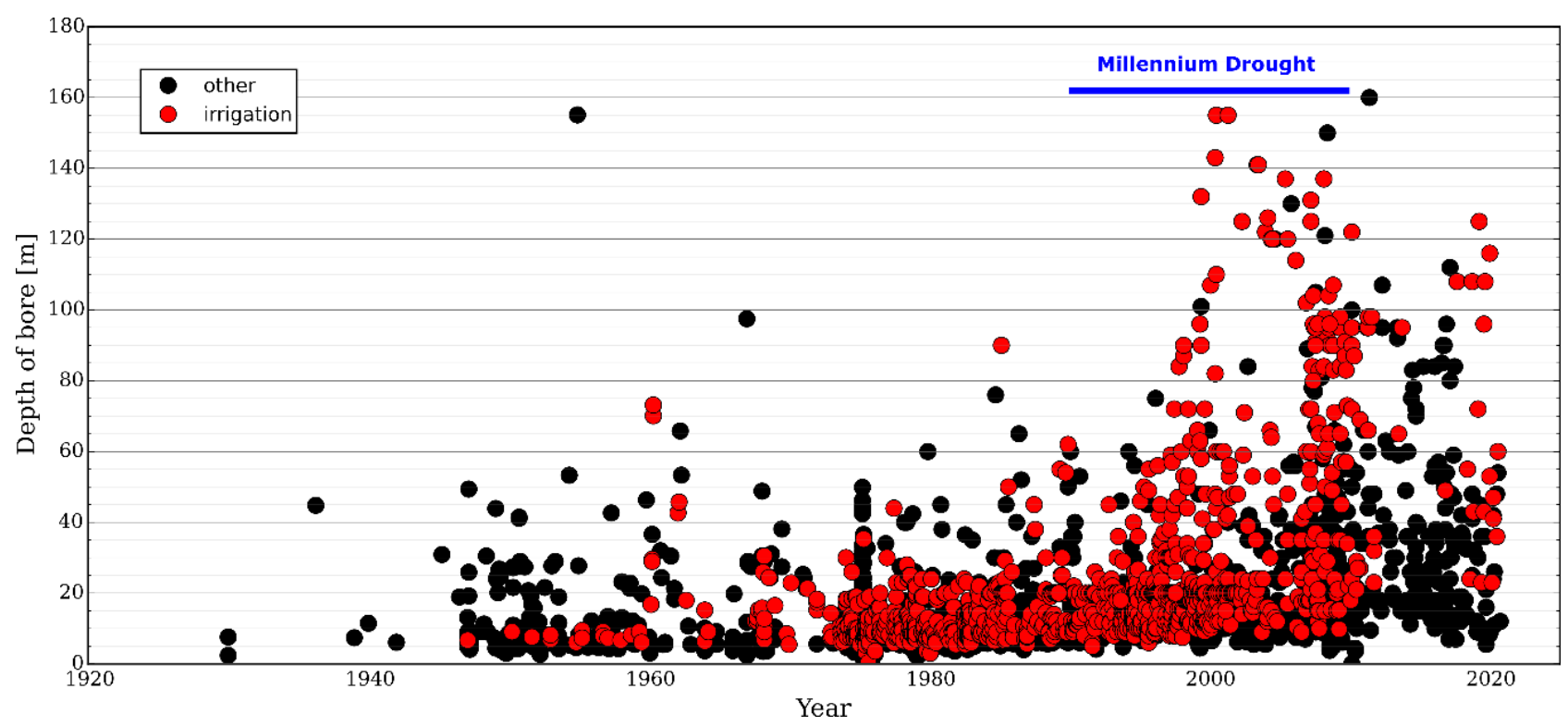

Figure 9. The drilled depth of bores in the study area has increased since the mid-1990s, coinciding with the onset of the “Millennium Drought." Data obtained from the SA Government Groundwater Data: Obswell database [40].

In addition to the above, it can be speculated that the transition from flood/pivot irrigation to drip irrigation systems over the last few decades would have further exacerbated the clogging problem. Drip irrigation systems, with their very narrow emitters may have increased the susceptibility of irrigation systems to clog up.

A correlation between changes in climate and irrigation practices and the widening of the clogging problem has not been postulated to date. Instead, many irrigators view contamination through drilling equipment as the likely route cause of the problem. As 
changes in climate and irrigation practices are impacting the study area very gradually, its follow-on impacts on clogging in the region would have not been easily discernible, however, these changes are regarded as the most likely cause of the widening problem to date.

\section{Limitations}

A major limitation in the current study has been the reliance on self-reporting on the clogging status of a bore by bore owners in the absence of a quantitative measure of iron clogging. This would have introduced significant bias. The absence of an adoptable scale for the severity of clogging, impacted on the ability to correlate between the severity and operational/chemical/biological indicators. Future work in this area would benefit from the development of a standard and systematic approach in determining the clogging status of a well based on quantitative measures. A larger sample size is also needed to explore the statistical significance of observed correlations and relationships.

Author Contributions: Conceptualization and methodology: I.W., H.W., K.D., and N.H.; field and laboratory analysis: B.M., M.B., and T.P.K.; data analysis and interpretation: B.M., I.W., H.W., K.D., and N.H.; writing — original draft preparation: B.M. and M.B.; writing-review and editing, I.W. and H.W. All authors have read and agreed to the published version of the manuscript.

Funding: This research was funded by Wine Australia, through its Incubator Initiative.

Institutional Review Board Statement: Not applicable.

Informed Consent Statement: Not applicable.

Data Availability Statement: Not applicable.

Acknowledgments: Funding for this project was provided by Wine Australia through its Incubator Initiative. In-kind support was provided by Flinders University. Thanks to Rachel Roberts (Flinders University) for providing input to the current work and assistance during field work and Robert Keane (Flinders University) for generating the map image. Our thanks go to all of the irrigators who took the time to meet and provide information, as well as providing access to irrigation bores. The funders had no role in the design of the study; in the collection, analyses, or interpretation of data; in the writing of the manuscript; or in the decision to publish the results.

Conflicts of Interest: The authors declare no conflict of interest.

\section{Appendix A}

Table A1. Overview of the inorganic groundwater chemistry.

\begin{tabular}{|c|c|c|c|c|c|c|}
\hline Components & Units & Min & $\operatorname{Max}$ & Average & Median & $n$ \\
\hline $\mathrm{pH}$ & & 7.4 & 8.0 & 7.7 & 7.7 & 26 \\
\hline E.C. & $\mathrm{dS} / \mathrm{m}$ & 1.4 & 2.8 & 1.8 & 1.8 & 26 \\
\hline $\begin{array}{l}\text { Total alkalinity as } \\
\qquad \mathrm{CaCO}_{3}\end{array}$ & $\mathrm{mg} / \mathrm{L}$ & 270 & 429 & 341 & 336 & 26 \\
\hline NPOC & $\mathrm{mg} / \mathrm{L}$ & 0.1 & 1.9 & 1.2 & 1.3 & 26 \\
\hline $\mathrm{F}$ & $\mathrm{mg} / \mathrm{L}$ & 0.2 & 0.7 & 0.3 & 0.3 & 26 \\
\hline $\mathrm{Cl}$ & $\mathrm{mg} / \mathrm{L}$ & 319 & 771 & 436 & 413 & 26 \\
\hline $\mathrm{Br}$ & $\mathrm{mg} / \mathrm{L}$ & 0.6 & 2.0 & 1.1 & 0.9 & 26 \\
\hline $\mathrm{NO}_{3}$ & $\mathrm{mg} / \mathrm{L}$ & 0.2 & 93.3 & 21.7 & 8.7 & 26 \\
\hline $\mathrm{SO}_{4}$ & $\mathrm{mg} / \mathrm{L}$ & 17.3 & 133 & 59.0 & 51.6 & 26 \\
\hline $\mathrm{Ca}$ & $\mathrm{mg} / \mathrm{L}$ & 103 & 165 & 131 & 128 & 26 \\
\hline K & $\mathrm{mg} / \mathrm{L}$ & 3.6 & 8.3 & 5.2 & 4.9 & 26 \\
\hline $\mathrm{Mg}$ & $\mathrm{mg} / \mathrm{L}$ & 22.9 & 55.5 & 36.5 & 34.9 & 26 \\
\hline $\mathrm{Na}$ & $\mathrm{mg} / \mathrm{L}$ & 147 & 353 & 198 & 179 & 26 \\
\hline B & $\mathrm{mg} / \mathrm{L}$ & 0.1 & 0.4 & 0.1 & 0.1 & 26 \\
\hline $\mathrm{P}$ & $\mathrm{mg} / \mathrm{L}$ & $<0.2$ & $<0.2$ & na & na & 26 \\
\hline $\mathrm{Si}$ & $\mathrm{mg} / \mathrm{L}$ & 7.4 & 13.6 & 9.9 & 10.0 & 26 \\
\hline
\end{tabular}


Table A1. Cont.

\begin{tabular}{|c|c|c|c|c|c|c|}
\hline Components & Units & Min & Max & Average & Median & $n$ \\
\hline $\mathrm{Sr}$ & $\mathrm{mg} / \mathrm{L}$ & 0.8 & 2.3 & 1.3 & 1.3 & 26 \\
\hline $\mathrm{Be}$ & ug/L & $<0.1$ & $<0.1$ & na & na & 26 \\
\hline $\mathrm{Al}$ & $\mathrm{ug} / \mathrm{L}$ & $<0.5$ & 1.7 & 0.1 & 0.0 & 26 \\
\hline V & $\mathrm{ug} / \mathrm{L}$ & $<0.05$ & 4.5 & 1.0 & 0.6 & 26 \\
\hline $\mathrm{Cr}$ & $\mathrm{ug} / \mathrm{L}$ & $<0.2$ & 0.8 & 0.1 & 0.0 & 26 \\
\hline $\mathrm{Mn}$ & $\mathrm{ug} / \mathrm{L}$ & $<0.2$ & 117.7 & 11.5 & 5.0 & 26 \\
\hline $\mathrm{Fe}$ & $\mathrm{ug} / \mathrm{L}$ & $<0.8$ & 1460 & 332 & 12.4 & 26 \\
\hline Co & $\mathrm{ug} / \mathrm{L}$ & $<0.05$ & 0.9 & 0.1 & 0.0 & 26 \\
\hline $\mathrm{Ni}$ & $\mathrm{ug} / \mathrm{L}$ & 0.2 & 3.1 & 0.8 & 0.5 & 26 \\
\hline $\mathrm{Cu}$ & $\mathrm{ug} / \mathrm{L}$ & 0.1 & 8.7 & 1.4 & 0.8 & 26 \\
\hline $\mathrm{Zn}$ & $\mathrm{ug} / \mathrm{L}$ & 1.0 & 85.4 & 14.2 & 9.5 & 26 \\
\hline $\mathrm{Ga}$ & $\mathrm{ug} / \mathrm{L}$ & $<0.05$ & $<0.1$ & na & na & 26 \\
\hline As & $\mathrm{ug} / \mathrm{L}$ & $<0.4$ & 28.6 & 4.4 & 1.5 & 26 \\
\hline Se & $\mathrm{ug} / \mathrm{L}$ & 0.3 & 5.2 & 1.7 & 1.2 & 26 \\
\hline Mo & $\mathrm{ug} / \mathrm{L}$ & $<0.2$ & 0.7 & 0.2 & 0.0 & 26 \\
\hline $\mathrm{Ag}$ & $\mathrm{ug} / \mathrm{L}$ & $<0.1$ & $<0.1$ & na & na & 26 \\
\hline $\mathrm{Cd}$ & $\mathrm{ug} / \mathrm{L}$ & $<0.05$ & 1.8 & 1.2 & 1.3 & 26 \\
\hline Sn & $\mathrm{ug} / \mathrm{L}$ & $<0.4$ & $<0.4$ & na & na & 26 \\
\hline $\mathrm{Sb}$ & $\mathrm{ug} / \mathrm{L}$ & $<0.2$ & $<0.2$ & na & na & 26 \\
\hline $\mathrm{La}$ & $\mathrm{ug} / \mathrm{L}$ & $<0.05$ & $<0.05$ & na & na & 26 \\
\hline $\mathrm{Tl}$ & $\mathrm{ug} / \mathrm{L}$ & $<0.1$ & $<0.1$ & na & na & 26 \\
\hline $\mathrm{Pb}$ & $\mathrm{ug} / \mathrm{L}$ & $<0.1$ & 3.0 & 1.7 & 1.7 & 26 \\
\hline $\mathrm{Bi}$ & $\mathrm{ug} / \mathrm{L}$ & $<0.1$ & $<0.1$ & na & na & 26 \\
\hline $\mathrm{U}$ & $\mathrm{ug} / \mathrm{L}$ & $<0.1$ & 2.1 & 0.4 & 0.2 & 26 \\
\hline
\end{tabular}

Table A2. Microbial analysis of sampled bores and the iron clogging status. All samples (expect bore number 16 and 24 were sampled after purging. Bore number 16 and 24 were sampled without purging).

\begin{tabular}{|c|c|c|c|c|c|c|}
\hline Bore No. & Drill Date & Depth To (m) & IRB * & $\begin{array}{l}\text { Coliform } \\
\text { Bacteria }\end{array}$ & $\begin{array}{c}\text { E. coli } \\
\text { (MPN/100 mL) }\end{array}$ & Iron Clogging \\
\hline 1 & & 7.65 & + & + & 0 & Unaffected \\
\hline 2 & 1994 & 50 & + & + & 0 & $\begin{array}{l}\text { Affected to a } \\
\text { minor/moderate degree }\end{array}$ \\
\hline 3 & 2001 & 52 & + & + & 0 & $\begin{array}{l}\text { Affected to a } \\
\text { minor/moderate degree }\end{array}$ \\
\hline 4 & 1994 & 50 & + & + & 0 & Strongly affected \\
\hline 5 & 1994 & 50 & + & + & 0 & Unaffected \\
\hline 6 & 1980 & 8.5 & + & + & 51.2 & Strongly affected \\
\hline 7 & & & + & + & 9.7 & Strongly affected \\
\hline 8 & 2007 & 30 & ++ & + & 0 & Strongly affected \\
\hline 9 & 1990 & 20 & - & + & 0 & Unaffected \\
\hline 10 & 1989 & 20 & + & + & 0 & Unaffected \\
\hline 11 & & Shallow & + & + & 0 & Unaffected \\
\hline 12 & 2006 & 102 & - & - & 0 & Strongly affected \\
\hline 13 & $\begin{array}{l}1993 \text { to } 18 \mathrm{~m} \text { then } \\
\text { deepened to } 96 \mathrm{~m} \text { in } \\
2008\end{array}$ & 96 & ++ & + & 0 & Strongly affected \\
\hline 14 & 2008 & 92 & - & - & 0 & Strongly affected \\
\hline 15 & $\begin{array}{l}1971 \text { to } 21.3 \mathrm{~m} \text { then } \\
\text { deepened in } 2008 \text { to } \\
90 \mathrm{~m}\end{array}$ & 90 & + & + & 0 & Strongly affected \\
\hline 16 & & 65 & ++ & + & 24.6 & Strongly affected \\
\hline 17 & 1979 & 16 & + & + & 0 & Unknown \\
\hline
\end{tabular}


Table A2. Cont.

\begin{tabular}{|c|c|c|c|c|c|c|}
\hline Bore No. & Drill Date & Depth To (m) & IRB * & $\begin{array}{l}\text { Coliform } \\
\text { Bacteria }\end{array}$ & $\begin{array}{c}\text { E. coli } \\
\text { (MPN/100 mL) }\end{array}$ & Iron Clogging \\
\hline 18 & & & + & + & 0 & $\begin{array}{c}\text { Affected to a } \\
\text { minor/moderate degree }\end{array}$ \\
\hline 19 & & & + & + & 0 & Unknown \\
\hline 20 & 1981 & 20 & na & na & na & No sample \\
\hline 21 & 2006 & 30 & ++ & + & 7 & $\begin{array}{c}\text { Affected to a } \\
\text { minor/moderate degree }\end{array}$ \\
\hline 22 & & & + & + & 2 & Unaffected \\
\hline 23 & 2016 & 54 & + & + & 0 & Unaffected \\
\hline 24 & $\begin{array}{l}1985 \text { to } 24 \mathrm{~m}, \\
\text { deepened in } 2006 \text { to } \\
60 \mathrm{~m}\end{array}$ & $60 \mathrm{~m}$ & ++ & + & 2 & Strongly affected \\
\hline 25 & & & + & + & 0 & Unaffected \\
\hline 26 & 1996 & 40 & + & + & 6 & Unaffected \\
\hline
\end{tabular}

* Positive or negative according to the IRB BART test.

\section{References}

1. Houben, G.J.; Weihe, U. Spatial distribution of incrustations around a water well after 38 years of use. Groundwater 2010, 48, 53-58. [CrossRef]

2. Wang, J.; Sickinger, M.; Ciobota, V.; Herrmann, M.; Rasch, H.; Rösch, P.; Popp, J.; Küsel, K. Revealing the microbial community structure of clogging materials in dewatering wells differing in physico-chemical parameters in an open-cast mining area. Water Res. 2014, 63, 222-233. [CrossRef] [PubMed]

3. Harrington, N.M.; Harrington, G.A. Best Management Practices for Irrigation Water Quality Issues in the Limestone Coast. Region. of South. Australia; A Report Prepared for the Limestone Coast Grape and Wine Council and the South East Natural Resources Management Board; Innovative Groundwater Solutions Pty Ltd.: Victor Harbor, Australia, 2016.

4. McLaughlan, R.G. Corrosion and Incrustation in Groundwater Bores: A Critical Review; Centre for Groundwater Management and Hydrogeology, University of New South Wales: Sydney, Australia, 1989.

5. Tong, M.; Yuan, S.; Zhang, P.; Liao, P.; Alshawabkeh, A.N.; Xie, X.; Wang, Y. Electrochemically induced oxidative precipitation of fe (ii) for as (iii) oxidation and removal in synthetic groundwater. Environ. Sci. Technol. 2014, 48, 5145-5153. [CrossRef] [PubMed]

6. Grenthe, I.; Stumm, W.; Laaksuharju, M.; Nilsson, A.; Wikberg, P. Redox potentials and redox reactions in deep groundwater systems. Chem. Geol. 1992, 98, 131-150. [CrossRef]

7. Teutsch, N.; von Gunten, U.; Porcelli, D.; Cirpka, O.A.; Halliday, A.N. Adsorption as a cause for iron isotope fractionation in reduced groundwater. Geochim. Cosmochim. Acta 2005, 69, 4175-4185. [CrossRef]

8. Gino, E.; Starosvetsky, J.; Kurzbaum, E.; Armon, R. Combined chemical-biological treatment for prevention/rehabilitation of clogged wells by an iron-oxidizing bacterium. Environ. Sci. Technol. 2010, 44, 3123-3129. [CrossRef]

9. Sun, H.; Shi, B.; Lytle, D.A.; Bai, Y.; Wang, D. Formation and release behavior of iron corrosion products under the influence of bacterial communities in a simulated water distribution system. Environ. Sci. Process. Impacts 2014, 16, 576-585. [CrossRef] [PubMed]

10. Gong, J.; Erkelens, M.; Lambert, M.F.; Forward, P. Experimental study of dynamic effects of iron bacteria-formed biofilms on pipeline head loss and roughness. J. Water Resour. Plan. Manag. 2019, 145, 04019038. [CrossRef]

11. Emerson, D.; Moyer, C. Isolation and characterization of novel iron-oxidizing bacteria that grow at circumneutral ph. Appl. Environ. Microbiol. 1997, 63, 4784-4792. [CrossRef] [PubMed]

12. Emerson, D.; Fleming, E.J.; McBeth, J.M. Iron-oxidizing bacteria: An environmental and genomic perspective. Annu. Rev. Microbiol. 2010, 64, 561-583. [CrossRef]

13. Donlan, R.M. Biofilms: Microbial life on surfaces. Emerg. Infect. Dis. 2002, 8, 881-890. [CrossRef]

14. Houben, G.; Sander, J. Preventing the growth of iron bacteria in water wells by copper and silver coating. Water Supply 2020, 20, 1195-1206. [CrossRef]

15. Baveye, P.; Vandevivere, P.; Hoyle, B.L.; DeLeo, P.C.; de Lozada, D.S. Environmental impact and mechanisms of the biological clogging of saturated soils and aquifer materials. Crit. Rev. Environ. Sci. Technol. 2010, 28, 123-191. [CrossRef]

16. Vandevivere, P.; Baveye, P. Effect of bacterial extracellular polymers on the saturated hydraulic conductivity of sand columns. Appl. Environ. Microbiol. 1992, 58, 1690-1698. [CrossRef] [PubMed]

17. Fleming, I.R.; Rowe, R.K. Laboratory studies of clogging of landfill leachate collection and drainage systems. Can. Geotech. J. 2004, 41, 134-153. [CrossRef]

18. Fleming, I.; Rowe, R.; Cullimore, D.R. Field observations of clogging in a landfill leachate collection system. Can. Geotech. J. 1999, 36, 685-707. [CrossRef] 
19. Straub, K.L.; Benz, M.; Schink, B. Iron metabolism in anoxic environments at near neutral ph. FEMS Microbiol. Ecol. 2001, 34, 181-186. [CrossRef]

20. Davison, W.; Seed, G. The kinetics of the oxidation of ferrous iron in synthetic and natural waters. Geochim. Cosmochim. Acta 1983, 47, 67-79. [CrossRef]

21. Singh, V.K.; Singh, A.L.; Singh, R.; Kumar, A. Iron oxidizing bacteria: Insights on diversity, mechanism of iron oxidation and role in management of metal pollution. Environ. Sustain. 2018, 1, 221-231. [CrossRef]

22. Neubauer, S.C.; Emerson, D.; Megonigal, J.P. Life at the energetic edge: Kinetics of circumneutral iron oxidation by lithotrophic iron-oxidizing bacteria isolated from the wetland-plant rhizosphere. Appl. Environ. Microbiol. 2002, 68, 3988-3995. [CrossRef] [PubMed]

23. Rentz, J.A.; Kraiya, C.; Luther, G.W.; Emerson, D. Control of ferrous iron oxidation within circumneutral microbial iron mats by cellular activity and autocatalysis. Environ. Sci. Technol. 2007, 41, 6084-6089. [CrossRef]

24. Longbottom, M.; Maschmedt, D.; Pichler, M. Unearthing Viticulture in the Limestone Coast.-The Climate, Geology, Soils, Hydrology and Environment of South. Australia's Limestone Coast; Limestone Coast Grape Wine Industry Council: Coonawarra, Australia, 2011.

25. Harrington, N.M.; Harrington, G.A. A Survey on the Water Quality Issues Facing Irrigators in the Limestone Coast. Region. of South. Australia. Board; A report prepared, Innovative Groundwater Solutions for the Limestone Coast Grape and Wine Council and the South East Natural Resources Management; Innovative Groundwater Solutions: Adelaide, Australia, 2016.

26. Kyser, T.K.; James, N.P.; Bone, Y. Shallow burial dolomitization and dedolomitization of cenozoic cool-water limestones, southern australia: Geochemistry and origin. J. Sediment. Res. 2002, 72, 146-157. [CrossRef]

27. Department for Water. South. East. Water Science Review; Lower Limestone Coast Water Allocation Plan Taskforce: Adelaide, Australia, 2010.

28. South Eastern Australian Climate Initiative; CSIRO. Climate Variability and Change in South-Eastern Australia: A Synthesis of Findings from Phase 1 of the South. Eastern Australian Climate Initiative; CSIRO: Canberra, Australia, 2010.

29. Parkhurst, D.L.; Appelo, C.A.J. User's Guide to Phreeqc (Version 2): A Computer Program. for Speciation, Batch-Reaction, OneDimensional Transport, and Inverse Geochemical Calculations; Water-Resources Investigations Report 99-4259; U.S. Geological Survey: Denver, CO, USA, 1999.

30. Plummer, L.; Parkhurst, D.; Wigley, T. Critical review of the kinetics of calcite dissolution and precipitation. ACS Symp. Ser. 1979, 93, 537-573. [CrossRef]

31. Vandenbohede, A.; Wallis, I.; Van Houtte, E.; Van Ranst, E. Hydrogeochemical transport modeling of the infiltration of tertiary treated wastewater in a dune area, belgium. Hydrogeol. J. 2013, 21, 1307-1321. [CrossRef]

32. Smedley, P.L.; Kinniburgh, D.G. A review of the source, behaviour and distribution of arsenic in natural waters. Appl. Geochem. 2002, 17, 517-568. [CrossRef]

33. Wallis, I.; Pichler, T. Generating false negatives and false positives for as and mo concentrations in groundwater due to well installation. Sci. Total. Environ. 2018, 631, 723-732. [CrossRef]

34. Neal, R.H.; Sposito, G. Selenate adsorption on alluvial soils. Soil Sci. Soc. Am. J. 1989, 53, 70-74. [CrossRef]

35. Jakobsen, R.; Postma, D. Redox zoning, rates of sulfate reduction and interactions with fe-reduction and methanogenesis in a shallow sandy aquifer, rømø, denmark. Geochim. Cosmochim. Acta 1999, 63, 137-151. [CrossRef]

36. Burté, L.; Cravotta III, C.A.; Bethencourt, L.; Farasin, J.; Pédrot, M.; Dufresne, A.; Gérard, M.-F.O.; Baranger, C.; Le Borgne, T.; Aquilina, L. Kinetic study on clogging of a geothermal pumping well triggered by mixing-induced biogeochemical reactions. Environ. Sci. Technol. 2019, 53, 5848-5857. [CrossRef]

37. Nhmrc, N. Australian Drinking Water Guidelines; National Health and Medical Research Council and Natural Resource Managment Ministerial Council: Canberra, Australia, 2011.

38. Harrington, N.; Millington, A.; Sodahlan, M.; Phillips, D. Development of Preliminary 1969 and 1983 Land use Maps for the South. East. of Sa; Research Technical Report Series No. 15/16; Goyder Institute for Water: Adelaide, Australia, 2015.

39. Chowdhury, R.K.; Beecham, S.; Boland, J.; Piantadosi, J. Understanding south australian rainfall trends and step changes. Int. J. Climatol. 2015, 35, 348-360. [CrossRef]

40. South Australian Government Obswell Database. Available online: www.waterconnect.sa.gov.au (accessed on 26 August 2020 ). 